\title{
Biological activity and persistence of pirimiphos-methyl applied to maize grain at different temperatures
}

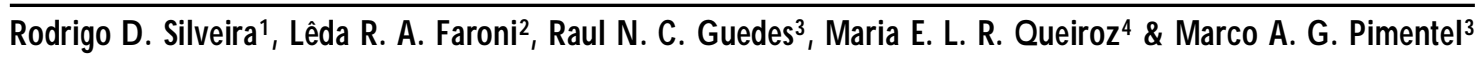

\begin{abstract}
The expansion of dryeration may impose a further problem for insect control with protectants - the high grain temperatures during insecticide spraying. To assess the impact of this procedure on insecticide activity, maize grains at different temperatures $\left(25,30,35,40\right.$ and $\left.45^{\circ} \mathrm{C}\right)$ were sprayed with pirimiphos-methyl. Residue analyses were carried out every 30 days and insecticide biological activity towards Sitophilus zeamais and Tribolium castaneum was assessed every 15 days throughout the experimental period of 90 days. Insect mortality was eval uated after $48 \mathrm{~h}$. Pirimiphos-methyl residue decreased with increased storage time and grain temperature during spraying. Similar trends were also observed for mortality of S. zeamais and T. castaneum, which dropped from around $100 \%$ for lower grain temperatures, shortly after spraying, to mortality values around $0 \%$ for higher temperatures and after 90 days of storage. These results indicate the drastic effect of grain temperatures during spraying, which compromises the efficiency of grain protectants for insect pest control on stored grains.
\end{abstract}

Key words: Sitophilus zeamais, Tribolium castaneum, organophosphate, residue, insect control

\section{Eficácia biológica e persistência do pirimifós-metil aplicados sobre grãos de milho em diferentes temperaturas}

\begin{abstract}
RESU MO
A técnica de seca-aeração pode causar problema no controle de insetos devido à alta temperatura do grão durante 0 processo de pulverização do inseticida. Com este trabal ho objetivou-se avaliar o efeito imediato e latente da temperatura do grão durante o processo de pulverização sobre a persistência e eficácia biológica do inseticida pirimifós-metil no controle de Sitophilus zeamais e Tribolium castaneum. Para tal, pulverizou-se 0 inseticida pirimifós-metil sobre os grãos de milho quando se apresentavam nas temperaturas de $25,30,35,40$ e $45^{\circ} \mathrm{C}$. A análise de resíduo foi realizada após a pulverização e a cada 30 dias, até 90 dias. Para avaliação da eficácia biológica 20 insetos adul tos de $\mathrm{S}$. zeamais e de T. castaneum foram colocados em uma placa de Petri contendo grãos tratados e, após $48 \mathrm{~h}$ de exposição dos insetos aos grãos, logo depois da pulverização e a cada 15 dias, até 90 dias, foram realizadas as avaliações. 0 bservou-se que a eficácia biológica do pirimifós-metil reduziu durante o período de armazenamento e que 0 aumento da temperatura do grão no momento da pulverização também contribui para a redução da eficácia deste inseticida. O bservou-se, também, que $\mathrm{S}$. zeamais apresentou menor sensibilidade ao pirimifós-metil que T. castaneum.
\end{abstract}

Palavras-chave: Sitophilus zeamais, Tribolium castaneum, organofosforado, resíduo, controle de inseto

\footnotetext{
1 UFVJM, CEP 39100-000, Diamantina, MG. Fone: (38) 3532-1226. E-mail: rodrigo-ufvjm@hotmail.com

2 DEA/UFV, CEP 36571-000, Viçosa, M G. Fone: (31) 3899-1874. E-mail: Ifaroni@ufv.br

3 DBA/U FV, Fone: (31) 3899-4008. E-mail: guedes@ufv.br, marcoagp@gmail.com

4 DEQ/UFV, Fone: (31) 3899-1430. E-mail: meliana@ufv.br
} 


\section{INTRODUCTION}

Several factors may contribute to the degradation of insecticides used for controlling insect pests in stored grains. Among them, air and grain temperature and moisture content are better studied and of major importance (Arthur et al., 1992; Wintersteen \& Foster, 1992; White \& Leesch, 1996; Fleurat-Lessard et al., 1998; Hamacher et al., 2002; Pimentel et al., 2004). High grain temperatures, for instance, cause fast breakdown of many insecticides, mainly by stimulating grain hydrolytic enzymes (Rowlands, 1975; Orth \& Minett, 1975).

Dryeration techniques are increasingly used in Brazil and may impose a further problem for insect control with protectants in the tropics - the high grain temperatures during insecticide spraying. These techniques aim at energy savings, high drying capacity and lower thermal damage by long grain exposure to high temperatures (Silveira, 2002). If using dryeration, the warm grain is removed from the drier with up to $2.5 \%$ higher moisture content than recommended for storage. The grain is then transferred to a bin where it remains from 4 to $10 \mathrm{~h}$ to allow moisture distribution within the grain by residual heat. This process facilitates the removal of excess moisture during about $12 \mathrm{~h}$ of aeration, which will take place afterwards until the grain reaches the desired moisture content. However, the grain usually remains in the same bin after the resting period for the aeration, and the insecticide spraying takes place while conveying the grain from the drier to the bin, when grain temperature reaches over $45^{\circ} \mathrm{C}$ (Mourier \& Poulsen, 2000).

The organophosphate pirimiphos-methyl, one of the main grain protectants used against stored product insects in Brazil, is frequently used in these operations (Andrei, 1999) and the procedure described above (spraying at high grain temperatures) is a potential problem for stored product protection because organophosphate degradation is usually faster at high temperatures (Arthur et al., 1992; White \& Leesch, 1996; Daglish, 1998; Fleurat-Lessard et al., 1998; Faroni et al., 2002; Hamacher et al., 2002; Pimentel et al., 2004) compromising even further the already difficult control of stored product insects in tropical areas. Therefore, the objective of the present study was to assess the impact of high grain temperatures during spraying on pirimiphos-methyl persistence and activity towards two important pest species of stored maize in the tropics - the maize weevil and the red flour beetle.

\section{MATERIAL AND METHODS}

The investigation was carried out in the Viçosa County, State of Minas Gerais, from December 2000 to January 2002, where maize grains of the variety AG-1051 harvested with $20 \%$ m.c. were dried to $15 \%$ m.c. in batches of $20 \mathrm{~kg}$ using an experimental drier with $1 \mathrm{~m} \mathrm{~s}^{-1}$ of drying air speed. Dried grains (15\% m.c.) at different temperatures $(25,30,35,40$ and $45^{\circ} \mathrm{C}$ ) were placed in a conveyor belt $1.0 \mathrm{~m}$ long and $0.2 \mathrm{~m}$ wide (Faroni et al., 2002; Hamacher et al., 2002). The belt capacity was $8.25 \mathrm{tha}^{-1}$ activated by an induction triphasic $0.5 \mathrm{hp}$ motor coupled with a $0.5 \mathrm{hp}$ motoreductor (with $24 \mathrm{x}$ reduction). A container with flow regulation was coupled to the conveyor belt to guarantee uniform grain flow in a thin layer throughout its length. The sprayer used for insecticide spraying at the conveyor belt was equipped with a single flat fan nozzle (Teejet TP650067) at $0.15 \mathrm{~m}$ high and regulated to deliver an application rate of $11.5 \mathrm{~mL} \mathrm{~min}^{-1}$ at 2 bar pressure.

The organophosphate insecticide pirimiphos-methyl (Actellic ${ }^{\circledR} 500 \mathrm{EC}$ ) was applied at the recommended concentration of $4.0 \mathrm{mg}$ a.i. $\mathrm{mL}^{-1}$ and $1.5 \mathrm{~mL}$ of insecticide solution was used per $\mathrm{kg}$ of maize (= $1.5 \mathrm{~L}$ per tonne of maize). The grain batches were left to rest for $6 \mathrm{~h}$ after spraying and then they were aerated for $12 \mathrm{~h}$ until reaching $13 \%$ m.c. Four batches of maize grains were sprayed at each temperature and $2.0 \mathrm{~kg}$ samples were taken from each batch and stored at $27 \pm 1{ }^{\circ} \mathrm{C}$ and $56 \pm 5 \%$ r.h. until the residue analysis and bioassay tests. Grain samples sprayed with water only were also used for the residue analysis and bioassay tests. The tests were carried out at the same environmental conditions of storage.

Insecticide residues on grain samples sprayed at the different temperatures were analyzed 0, 30, 60 and 90 days after spraying using three replicates. Non-sprayed grain samples were also analyzed for pirimiphos-methyl residues at the same storage intervals. Only analytical standards of the solvents were used for the residue analysis. Technical grade pirimiphos-methyl $(91.5 \%)$ was obtained from Zeneca Brasil (Holambra, SP, Brazil). The extraction methodology was adapted from Hamacher et al. (2002) and Luke et al. (1975). The efficiency of this extraction technique was assessed in three maize samples fortified with $1.0 \mathrm{~mL}$ standard solution of pirimiphos-methyl at $100.0 \mathrm{mg} \mathrm{mL}^{-1}$, allowing $86.1 \%$ recovery of the active ingredient. Ten grains of maize from each sample where mixed with acetone $(25 \mathrm{~mL})$, hexane $(10 \mathrm{~mL})$ and dichlorometane $(15 \mathrm{~mL})$ in an Erhlenmeyer flask and shaken for $30 \mathrm{~min}$. The extract was filtered through filter paper with $20 \mathrm{~g}$ of sodium sulfate and $15 \mathrm{~mL}$ dichlorometane was used to wash the paper at the end of the filtration. The extract was concentrated in a rotary evaporator at $40{ }^{\circ} \mathrm{C}$ and recovered to $4.0 \mathrm{~mL}$ with hexane. Sample extracts were analyzed in a gas chromatograph (Shymadzu CG-17A, Kyoto, Japan) equipped with a BP-5 column (poly $-5 \%$ diphenyl/95\% dimethylsiloxane, $30 \mathrm{~m} \mathrm{X} 0.25 \mathrm{~mm}$ i.d. and film thickness of $1 \mathrm{~mm}$ ) and a flame ionization detector (FID) (Faroni et al., 2002; Hamacher et al., 2002). Temperature of the column was $220{ }^{\circ} \mathrm{C}$ (7 min; isothermic), while the injector was maintained at $250{ }^{\circ} \mathrm{C}$ and the FID detector was maintained at $300{ }^{\circ} \mathrm{C}$. The flow of the carrier gas $(\mathrm{N})$ was $1.2 \mathrm{~mL} \mathrm{~min}^{-1}$, the split ratio was 1:5 and the injected volume was $1 \mathrm{~mL}$. Under these conditions, the pirimiphos-methyl retention time was about $4 \mathrm{~min}$. The setup values for the hydrogen, air and nitrogen make-up gas for the FID were $60 \mathrm{kPa}$ (approx. $50 \mathrm{~mL} \mathrm{~min}^{-1}$ ), $50 \mathrm{kPa}$ (approx. $500 \mathrm{~mL} \mathrm{~min}^{-1}$ ) and $75 \mathrm{kPa}$ (approx. $30 \mathrm{~mL} \mathrm{~min}^{-1}$ ), respectively. The residues were quantified directly from the calibration curve 
established within the detector linearity range, by comparing the sample peak areas with the peak areas of the external standards. The detector showed reasonable linearity within the work range from 0.2 to $10.0 \mathrm{mg} \mathrm{mL}^{-1}$, with $\mathrm{R}^{2}=0.994$, detection threshold of $0.2 \mathrm{mg} \mathrm{mL}^{-1}$ and quantification threshold of $0.6 \mathrm{mg} \mathrm{mL}^{-1}$.

The biological activity of pirimiphos-methyl sprayed at the five different temperatures was independently evaluated using non-sexed adults of maize weevil, Sitophilus zeamais Motschulsky (Coleoptera: Curculionidae), and of red flour beetle, Tribolium castaneum (Herst) (Coleoptera: Tenebrionidae). These insects were from laboratory colonies maintained at $27{ }^{\circ} \mathrm{C}$ and $55 \%$ r.h. on non-treated maize. Four $50 \mathrm{~g}$ samples of treated maize grains were taken from each treatment every 15 days up to 90 days after the insecticide spraying. These grain samples were placed in Petri dishes and infested with 20 insects of either species. They were maintained at $27{ }^{\circ} \mathrm{C}$ and $55 \%$ r.h. for $48 \mathrm{~h}$, after which the insect mortality was assessed. Mortality was corrected for the natural mortality on samples sprayed with water only.

Multiple regression analysis (SAS Institute, 1997) were used to determine whether the different grain temperatures at spraying and storage periods affected residue levels of pirimiphos-methyl on maize grains and the biological activity of this insecticide towards the maize weevil and the red flour beetle. Non-linear regression analyses were used to establish the relationship between residue levels and biological activity of pirimiphos-methyl. These analyses were carried out using the curve fitting procedure of SigmaPlot (SPSS INC, 2000).

\section{RESULTS AND DISCUSSION}

The residue level of pirimiphos-methyl on the grains shortly after spraying $(2 \mathrm{~h})$ were significantly smaller when this operation was carried out at higher grain temperatures with a nearly $80 \%$ difference between the extreme temperatures $\left(2.5 \pm 0.0 \mathrm{ppm}\right.$ at $45^{\circ} \mathrm{C}$ and $4.3 \pm 0.4 \mathrm{ppm}$ at $\left.25^{\circ} \mathrm{C}\right)$ (Figure 1). The differences remained, with time getting even greater at the end of the storage period, 90 days after spraying $\left(0.2 \pm 0.0 \mathrm{ppm}\right.$ at $45^{\circ} \mathrm{C}$ and $0.5 \pm 0.1 \mathrm{ppm}$ at $\left.25^{\circ} \mathrm{C}\right)$. The decrease in residue level was inversely related to grain temperatures and storage time. The effect of the air temperature favoring degradation of organophosphate insecticide residues on stored grains is widely recognized (Arthur et al., 1992; White \& Leesch, 1996; Fleurat-Lessard et al., 1998; Afridi et al., 2001).

High air temperatures, even if only during spraying, also showed a drastic effect on reducing pirimiphos-methyl residues on the grain surface and compromising insect control as demonstrated by Faroni et al. (2002) and Pimentel et al. (2004). In contrast, the effect of grain temperature in insecticide degradation was seldom explored. Wintersteen \& Foster (1992) did not observe any significant effect of grain dried under different systems in malathion degradation, unlike what was reported for pirimiphos-methyl. Such differences may be due to structural differences between

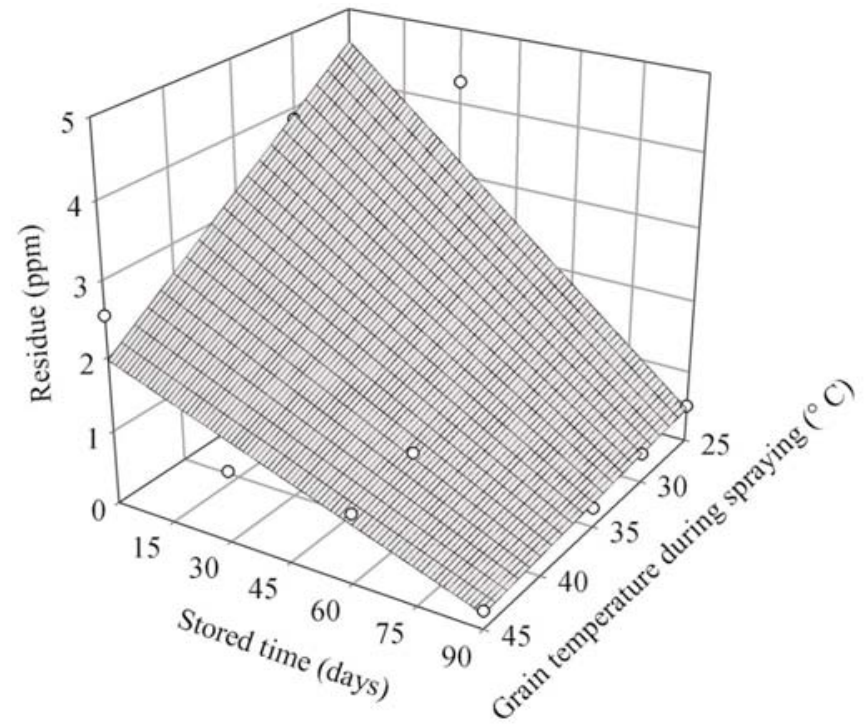

Figure 1. Effect of grain temperature, during spraying, and storage period (days) on the residue level of pirimiphos-methyl on maize grains. $(y=7.81-0.08 x-0.13 z+0.001 x z$; where $y=$ residue level $(p p m)$, $\mathrm{x}=$ storage period (days), and $\mathrm{z}=$ grain temperature during spraying $\left.\left({ }^{\circ} \mathrm{C}\right) ; \mathrm{R}^{2}=0.67 ; \mathrm{F}=24.26 ; \mathrm{p}<0.0001 ; \mathrm{df}_{\text {error }}=31\right)$

both compounds, but the high storage temperature used in the present study $\left(27^{\circ} \mathrm{C}\right)$ was a likely contributor to maximize insecticide degradation. The effect of the grain temperature during insecticide spraying on the degradation and activity of pirimiphos-methyl, demonstrated in our study, was expected based on previous studies assessing the effect of temperature speeding up insecticide degradation (Arthur et al., 1992; Daglish, 1998; Fleurat-Lessard et al., 1998; Afridi et al., 2001; Hamacher et al., 2002; Pimentel et al., 2004). However, residue levels of 50 to $80 \%$ higher at 25 than at $45{ }^{\circ} \mathrm{C}$ immediately after spraying, with 2 - to 4-fold drop during the 90-day storage period, were a surprise. The high grain temperatures at spraying may have led to insecticide losses through its suspension in the warm air surrounding the warm grain. This may have prevented the insecticide from reaching the grain surface and probably favored degradation on the grain surface as well. Evaporation of a volatile carrier (water in our case) can result in a decrease in droplet size to the point at which small droplets solidify, remaining suspended in the air and failing to adhere to the grain surface (Johnstone, 1985).

The decrease in the residue levels of pirimiphos-methyl in stored maize was also inversely related to mortality of the maize weevil and the red flour beetle (Figure 2). Insect mortality dropped quickly below 2 ppm, going from nearly $100 \%$ mortality to $0 \%$ for both insect species. Higher residue levels had negligible impact on insect mortality, which was already close to $100 \%$. High temperatures generally result in fast insecticide degradation, which seems particularly true in the case of organophosphates (Arthur et al., 1992; White \& Leesch, 1996; Daglish, 1998; Fleurat-Lessard et al., 1998). The lower persistence of pirimiphos-methyl residues on maize grains was translated into lower efficiency in controlling infestations of the maize weevil and red flour beetle. These relationships were non-linear, showing a great decrease in 
mortality with a decrease in residue levels from 2 to $1 \mathrm{ppm}$. Arthur et al. (1992) and Hamacher et al. (2002) also observed an increase in insect survival with a decrease in organophosphate residue levels on stored grains. The rate of reduction of residue levels indicates the length of protection provided by the insecticide. In all the instances investigated, with insecticide applications taking place with warm grains (from 25 to $45^{\circ} \mathrm{C}$ ) in a tropical area, the grain protection period will be greatly compromised.

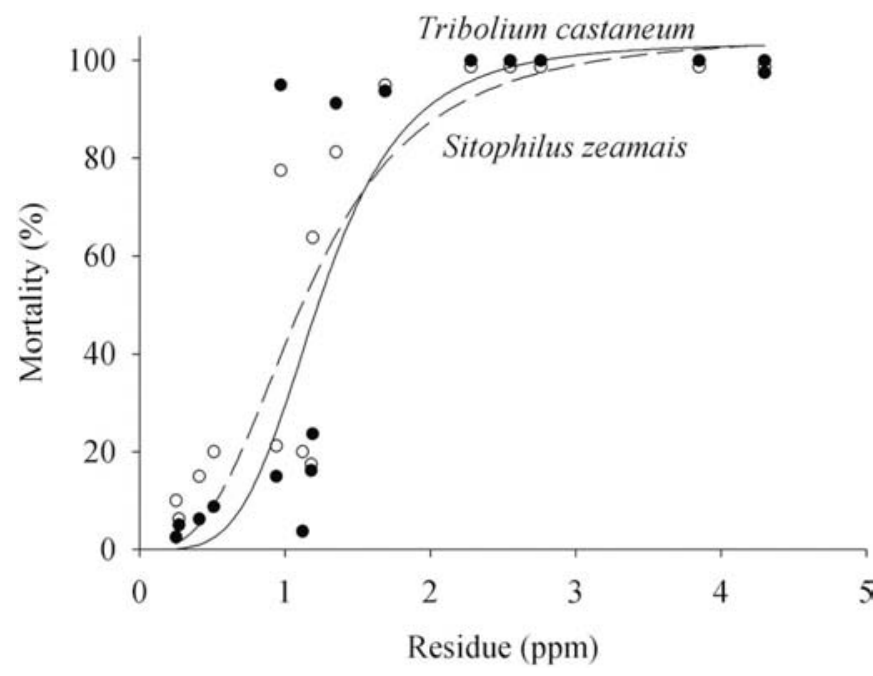

Figure 2. Relationship between residue levels of pirimiphos-methyl on stored maize and mortality of Sitophilus zeamais (open triangule; dotted line) and Tribolium castaneum (open circle; solid line). (S. zeamais: $y=105.54 /\left(1+(x / 1.71)^{-6.95}, \quad R^{2}=0.80, \quad F=32.35, \quad p<0.0001\right.$, $\mathrm{df}=14 ; \mathrm{T}$. castaneum: $\mathrm{y}=103.68 /\left(1+(\mathrm{x} / 1.25)^{-4.16}, \mathrm{R}^{2}=0.72\right.$ $\mathrm{F}=21.58, \mathrm{p}<0.0001, \mathrm{df}_{\text {error }}=14$ )

Insect mortality, as expected, decreased with an increase in grain temperature during spraying and period of storage (Figures 3A and 3B). Mortality was highest right after insecticide application for the highest temperature under investigation (i.e., $45^{\circ} \mathrm{C}$ ). The decrease in mortality was uniform with storage time and reached the lowest mortality levels faster when grains were sprayed at the highest temperatures for both insect species. There was no significant interaction between grain temperature at spraying and storage time for either insect species. A fast decrease was observed in residue levels and biological activity of pirimiphosmethyl during a 90-day storage period that was accentuated by the high grain temperatures during insecticide spraying. This finding is of importance because organophosphate spraying in tropical areas is frequently carried out on warm grain subjected to dryeration, which favors organophosphate degradation. A solution to minimize this problem is to avoid using the same bin for resting (allowing moisture distribution in the grain) and aeration (completing the grain drying). The use of two bins, one for resting the grain and another for aerating it, will allow spraying of the grain after its cooling at the resting bin while transporting it by the conveyor belt to the aerating bin. Such procedure will favor the residual effect of the insecticide providing suitable protection against insect-pests for longer storage periods.
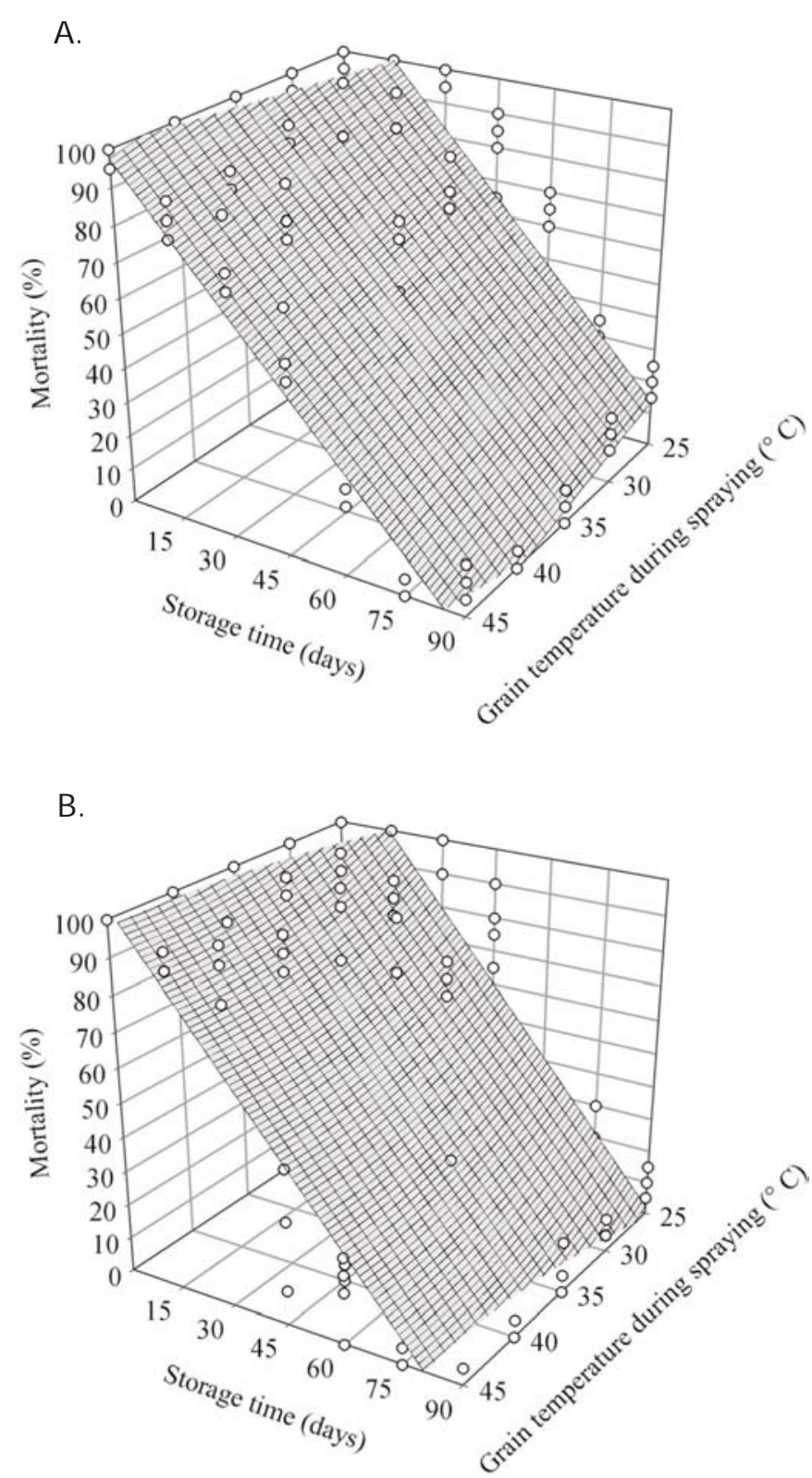

Figure 3. Effect of grain temperature during spraying with pirimiphos-methyl, and storage period (days) on the mortaltity of Sitophilus zeamais (A) $\left(y=141.65-1.15 x-0.98 z, \quad R^{2}=0.87, \quad F=116.96, \quad p<0.0001\right.$, $\mathrm{df}=32)$ and Tribolium castaneum (B) $(\mathrm{y}=188.32-1.29 \mathrm{x}-3.95 \mathrm{z}+$ $0.05 z^{2}, R^{2}=0.84, F=62.91, p<0.0001, d f_{\text {error }}=31$ )

\section{CONCLUSION}

These results clearly indicate the drastic effect of grain temperatures during spraying compromising the efficiency of grain protectants for insect pest control on stored grains.

\section{ACKNOWLEDGEMENTS}

To Dr. M.T. Martins (Department of Agricultural Engineering) from the Federal University of Viçosa, for his technical assistance; to Dr. D. Pedroni (Zeneca Brasil, Holambra, SP, Brazil) for providing the technical grade insecticide; 
and to CAPES, FAPEMIG and CNPq for providing us with financial support for the present investigation.

\section{LITERATURE CITED}

Afridi, I. A. K.; Parveen, Z.; Masud, S. Z. Stability of organophosphate and pyrethroid pesticides on wheat in storage. Journal of Stored Products Research, v.37, n.2, p.199-204, 2001.

Andrei, E. Compêndio de defensivos agrícolas. 6.ed. São Paulo: Andrei Editora Ltda, 1999. 672p.

Arthur, F. H.; Throne, J. E.; Simonaitis, R. A. Degradation and biological efficacy of chlorpyrifos-methyl on wheat stored at five temperatures and three moisture contents. Journal of Economic Entomology, v.85, n.5, p.1994-2002, 1992.

Daglish, G. J. Efficacy of six grain protectants applied alone or in combination against three species of coleoptera. Journal of Stored Products Research, v.34, n.4, p.263-268, 1998.

Faroni, L. R. A.; Guedes, R. N. C.; Queiroz, M. E. L. R.; Pimentel, M. A. G. Effect of the temperature during spraying on the biological efficiency of chemical protectants of stored grains. In: International Working Conference on Stored Product Protection, 8, 2002, Wallingford. Proceedings... Wallingford: CAB International. 2002. p.811-814.

Fleurat-Lessard, F.; Vidal, M. L.; Budzinski, H. Modeling biological efficacy decrease and rate of degradation of chlorpyrifos methyl on wheat stored under controlled conditions. Journal of Stored Products Research, v.34, n.4, p.341-354, 1998.

Hamacher, L. S.; Faroni, L. R. A.; Guedes, R. N. C.; Queiróz, M. E. L. R. Persistence and activity towards Sitophilus zeamais (Coleoptera: Curculionidae) of pirimiphos-methyl sprayed at different temperatures on maize. Journal of Stored Products Research, v.38, n.2, p.167-175, 2002.
Johnstone, D. R. Physics and meteorology. In: Haskell, P. T. (ed.). Pesticide application: Principles and practice. Oxford: Claredon, 1985. p.35-67.

Luke, M.; Frogerg, J. E.; Masumo, H. T. Extraction and clean up of organochlorine, organophosphate, organonitrogen and hydrocarbon pesticides in produce for determination by gas-liquid chromatography. Journal Association Analitical Chemistry, v.58, n.5, p.1020-1026, 1975.

Mourier, H.; Poulsen, K. P. Control of insects and mites in grain using a high temperature/short time (HTST) technique. Journal of Stored Products Research, v.36, n.3, p.309-318, 2000.

Orth, R. A.; Minett, W. Iodometric analysis and shelf life of malathion in formulations. Pesticide Science, v.6, n.1, p.217-221, 1975.

Pimentel, M. A. G.; Faroni, L. R. A.; Gonçalves, J. R.; Oliveira, C. R. F.; Alencar, E. R. Influência da temperatura na eficácia biológica de pirimifós metílico em milho armazenado. Revista Brasileira de Armazenamento, v.29, n.1, p.58-61, 2004.

Rowlands, D. G. The metabolism of contact insecticides in stored grain. Residue Reviews, v.58, n.1, p.113-155, 1975.

SAS Institute. User's guide: Statistics, version 6.12. 1.ed. Cary: SAS Institute, 1997. 1511p.

Silveira, R. D. Efeito da temperatura do grão, no momento da pulverização, sobre a degradação e a eficácia biológica do bifentrin e pirimifós-metil em milho. Viçosa: UFV, 2002.82p. Tese Doutorado

SPSS INC. SigmaPlot 2000 user's guide, Revised Edition. 1.ed. Chicago: SPSS Inc. 2000. 441p.

White, N. D. G.; Leesch, J. G. Chemical control. In: Subramanyam, B. H.; Hagstrum, D. W. (ed.). Integrated management of insects in stored products. New York: Marcel Dekker, 1996. cap.7, p.287-330.

Wintersteen, W. K.; Foster, D. E. Degradation of malathion as a function of grain drying systems. Journal of Economic Entomology, v.85, n.3, p.1015-1022, 1992. 